Nippon Suisan Gakkaishi $\quad$ 57(9), 1805 (1991)

短—報

\section{人工種苗マダイに対する 被捕食王学習効果}

山岡业作, 成田賢治, 山田徹生

小原邦俊, 谷口順彦

(1991 年 2 月 14 日受付)

Effects of Predation Pressure on the

Behaviour of Artifically-bred Juvenile Red Sea Bream

Kosaku Yamaoka,* Kenji Okada,*

Tetsuo Yamada,* Kunitoshi Kohara,* and Nobuhiko Taniguchi*

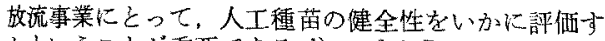
るかといらことが重要である。 マダイ Pagrus major の 場合，種苗性評洒のための指標の1つとして，捕食を避 けるそめの「横卧行動」が最近注目され始めた。本研究 ては，マダイ放流用人工種苗の種苗性改善のための被捕 食代学習害験を行い，文の過程で学習に上り横卧行動が 强化されたと考克られたので報告する。なお，「学罳」と は, 行勳が释験によって多少と承続的に変容すること (守局。

実駼㤬高知大学海洋生物教育研究センターで, 1990 年 7 月 18 日から7月 28 日まで計 4 回行った。芙験

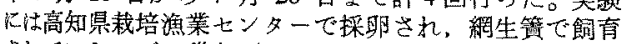
されていたマダイ稚黄（尾叉長 $21.60 \mathrm{~mm} \sim 61.66 \mathrm{~mm}$ ) 岂用いた。

1 回の実呀々は約 100 個体のマダイを使用した。 ず，無学習区として空腹状態にしたブリ奻魚（全長的 18 cm) 2 個体の入った円型 2 トン水槽にマダイを放流 L， 5 分間観察を行った。办㫪肉には人エアマモ (mariron) と建設用ブロック 1 塊 3 個を設圆した。氷槽の底面扎よ び僓面には色テープを貼り，円型水槽を目視により 4 等 分沤区別できるようにした。観察之同時に，上方よりマ
ダイとブリ幼魚の行動をビデオ画像により記録した。5 分間ブリ幼魚による捕食王に㩧した後，捕食されずに残 った個体を取り上げ，エアレーションを施した容器に入 れ放置した。30 分後に隣りに学習区として設置された ブリ纤魚 2 個体の入った同様の型水槽に放流した。こ の場合にす，無学習区と同しく5 分間の観察とビデオに よる記録を行った。ビデオ画像分析に際し，マダイを自 由遊泳個体と艺れ以外個体に区別し，30 秒每にビデ 才静止画像加自由遊泳個体を計数し1区割当りの平均 值を求めた。自由遊泳個体とは底などの基質に横卧した り世ず，遊泳し動回る個体で劣る。自由遊泳個体以外 の個体とは，横卧行動を示寸ものの他に，ブロックや人 エアマモの陰などに㩊れたものを含む。

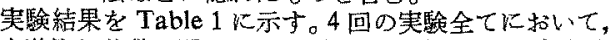
自由遊泳個体数に関して無学㕷区と学習区の間に有意差

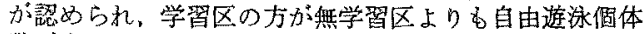
数が少なかった。このことは，ブリ幼魚による被捕食に 対する恐怖体験か，横臥行動等を示す個体数を増加さ せ，自由遊泳個体数を減少させたためと考充られる。

横臥行動を示すか否かはマダイ各個体の個性であり， 繰り返し実験してる再現性があるるのとされる。2)しか し，今回の結果はマダイの横卧行䣦関する個性は固定 したものではなく、後天的な体験等により变化しらるこ とを示唆する。今後, 種苗性々の関係で横卧行動の意義 をさら火検部するととあに, 被捕食王学習実験に上り横 臥行動と学習との関係や学習効果の持続性についてより 深く理解する必要方放る。

本実臤を行うにあたりご拹力頂いた高知県栽培漁業せ

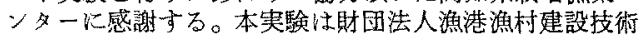
研究所より研究助成を受けたことを付記し，謝意を表す る。

\section{女 献}

1) 福原 修: マダイの盗源培恙技街（因中克， 松宮蒌睛編)，恒星社厚生閣，東京， 1986, pp. 26-36.

2) 榢本勝巳：さいばい，55, 20-24 (1990).

3)山田常雄ら編：岩波生物学辞典第 3 版：岩波書 告, 東京, 1985, p. 181 .

Table 1. Results of four experiments on the effects of predation pressure, raised by using yellowtail young fish, on the behaviour of artificially-bred juvenile red sea bream. $L$ and NL indicate the group learned and non-learned predation pressure, respectively

\begin{tabular}{|c|c|c|c|c|}
\hline & & $\begin{array}{l}\text { No. of } \\
\text { fish } \\
\text { used }\end{array}$ & $\begin{array}{l}\text { Mean and SD of } \\
\text { fork length of } \\
\text { fish used (mm) }\end{array}$ & $\begin{array}{l}\text { Mean and SD of } \% \text { of } \\
\text { swimming fish counted at } \\
\text { observation area each } 30 \\
\text { sec during } 5 \text { mins }(n=10)\end{array}$ \\
\hline Exp. 1 & $\begin{array}{l}\text { NL } \\
\text { L }\end{array}$ & $\begin{array}{l}n=110 \\
n=101\end{array}$ & $\begin{array}{c}38.13 \pm 7.77 \\
(n=20)\end{array}$ & $\begin{array}{c}10.86 \pm 5.13 \\
6.17 \pm 2.70^{* 1}\end{array}$ \\
\hline Exp. 2 & $\begin{array}{l}\mathrm{NL} \\
\mathrm{L}\end{array}$ & $\begin{array}{l}\mathrm{n}=102 \\
\mathrm{n}=91\end{array}$ & $\begin{array}{c}45.95 \pm 8.11 \\
(n=12)\end{array}$ & $\begin{array}{l}8.12 \pm 1.64 \\
0.28 \pm 0.69 * 2\end{array}$ \\
\hline Exp. 3 & $\begin{array}{l}\mathrm{NL} \\
\mathrm{L}\end{array}$ & $\begin{array}{l}\mathrm{n}=103 \\
\mathrm{n}=92\end{array}$ & $\begin{array}{c}48.16 \pm 9.68 \\
(n=10)\end{array}$ & $\begin{array}{c}10.17 \pm 5.67 \\
1.98 \pm 1.65^{* 2}\end{array}$ \\
\hline Exp. 4 & $\begin{array}{l}\mathrm{NL} \\
\mathrm{L}\end{array}$ & $\begin{array}{l}\mathrm{n}=103 \\
\mathrm{n}=100\end{array}$ & $\begin{array}{c}51.97 \pm 8.30 \\
(\mathrm{n}=10)\end{array}$ & $\begin{array}{l}8.28 \pm 2.97 \\
4.90 \pm 2.00^{* 1}\end{array}$ \\
\hline
\end{tabular}

${ }_{1, * 2}$ Significant differences were found between $\mathrm{NL}$ and $\mathrm{L}$ at $P<0.01$ and $P<0.001$, respectively, Mann-Whitney's $U$ test.

* 高知大学農学部 (Laboratory of Aquatic Ecology, Faculty of Agriculture, Kochi University, Nankoku, Kochi 783, Japan). 